\title{
Direct Impedimetric Detection and Isolation of Bacillus Cereus using Modified Platinum Electrode
}

\author{
Aashis S. Roy ${ }^{1,2}$ and Praveen C. Ramamurthy ${ }^{1,2, *}$ \\ ${ }^{1}$ Department of Materials Engineering, Indian Institute of Science, Bangalore, 560012, India \\ ${ }^{2}$ Center for Nanoscience and Engineering, Indian Institute of Science, Bangalore, 560012, India
}

\begin{abstract}
This work proposes a technique for isolation of bacteria using magnetic nanoparticles. The magnetic nanoparticles that are prepared by a sol-gel method using citric acid and nano-ferrites are characterized for structural and morphology by X-ray diffraction (XRD) and Transmission electron microscope (TEM), respectively. The prepared nano-ferrites coated with poly vinyl alcohol (PVA) over platinum electrode are used for detection of Bacillus Cereus. The isolated bacterial cells from colloidal solution are treated with zinc ferrite for $12 \mathrm{~h}$, and it is observed that the cells are coagulated with the nanoparticle when allowed to settle down. This is further filtered by different size of filter paper to get less than $0.1 \%$ of cells in water. Various electrochemical parameters like cyclovoltammetry (CV), sweep step function, Tafel plot, AC impedance are studied employing the modified platinum electrode. It is observed through $\mathrm{CV}$ graph that the peaks are formed at $-0.25 \mathrm{~V}$ due to the oxidation of bacterial cells, which is further supported by sweep step function graph. Therefore, this is one of the economically efficient techniques to detect and isolate the Bacillus cereus from a colloidal solution.
\end{abstract}

Keywords: Bacillus cereus, Magnetic nanoparticle, Cyclovoltammetry, Sweep step function.

\section{INTRODUCTION}

Bacillus cereus (B. Cereus) is one of the most common bacteria found in water and foods causing food poisoning and hence food borne illnesses [1, 2]. $W$ When the $B$. Cereus affects the stomach and intestine, symptoms such as nausea, vomiting, abnormal cramps and diarrhea are observed [3]. These symptoms may be incubated in the human body from short term to long term $[4,5]$. These bacterial cells of $B$. Cereus can grow in very extreme condition, such as temperature range of $10-50^{\circ} \mathrm{C}$ and $\mathrm{pH}$ of 2 to 11 , ingestion leads to the development of various types of toxins causing diarrhea and emetics [6, 7]. The three important toxins released from these bacteria are Hemolysin BL, Nonhemolytic enterotoxin, and Cytotoxin K. Therefore, it is important to detect and isolate these bacteria from drinking water [8] and food [9, 10].

The detection and isolation of bacteria [11, 12] with economically efficient technique at very low concentration is needed for present potable water purification system $[13,14]$. In particular, magnetic nanoparticles are used in detection, imaging, and isolation of bacteria at even low concentration from the drinking water $[15,16]$. The iron oxide nanoparticles, because of its easy synthesis, low cost and low toxicity are used in many medical applications and various

*Address correspondence to this author at the Department of Materials Engineering; Center for Nanoscience and Engineering, Indian Institute of Science, Bangalore, India; Tel: +91-80-2293-2627; Fax: +91-80-2360-0472; E-Mail: onegroupb203@gmail.com biotechnological fields [17] such as tissue repair, hyperthermia, magnetic resonance imaging, drug delivery system and molecular diagnosis $[18,19]$. The magnetic nanoparticles, quickly agglomerates because of their high surface energy and gets suspended in the solution [20, 21]. Furthermore, magnetic nanoparticles can be synthesized by various methods such as combustion, SPCR technique, co-precipitate, hydrothermal and solvothermal, interfacial method, sol gel methods, etc $[22,23]$. There is also a technique based on the magnetic response of $B$. Cereus $[24,25]$ with paramagnetic materials $[26,27]$ from the liquid suspension $[28,29]$.

Previous studies have showed that research has been carried out for isolation of various types of bacteria through microfluidics chip [3, 30], interdigitated microelectrodes [4, 9], employing gold electrodes [12], indium tin oxide electrodes for detection of pathogenic bacteria [14, 19], other polymers such as polypyrrole $[6,13]$ have also been studied. The above mentioned methods require sophisticated procedures and detail analysis [10].

Hence in this study, it is an attempt to isolate these pathogenic bacteria on PVA coated $\mathrm{ZnFe}_{2} \mathrm{O}_{4}$ over the platinum electrode [31]. Further various studies such as Cyclovoltammetry (CV), Sweep step function (SSF), Tafel plot (TP) and AC impedance are carried out [32, 33]. The magnetic nanoparticle is subjected to structural characterization by X-ray diffraction (XRD), and surface morphology is studied by Transmission electron microscope (TEM). The isolation is carried out 
on PVA coated $\mathrm{ZnFe}_{2} \mathrm{O}_{4}$ over the platinum electrode, and counting is carried out by hemocytometer with a different interval of time. After oxidation surface morphology studies of $B$. cereus is carried by Scanning electron microscope (SEM) to check the shrinking of cells.

\section{MATERIALS AND METHOD}

The synthesis of $\mathrm{ZnFe}_{2} \mathrm{O}_{4}$ nanocrystalline ferrite is carried out using Zinc Nitrate Hexahydrate $\left(\mathrm{Zn}\left(\mathrm{NO}_{3}\right)_{2} \cdot 6 \mathrm{H}_{2} \mathrm{O}\right)$, Citric acid Monohydrate $\left(\mathrm{C}_{6} \mathrm{H}_{8} \mathrm{O}_{7} \mathrm{H}_{2} \mathrm{O}\right)$ and Iron (III) Nitrate Nonahydrate $\left(\mathrm{Fe}\left(\mathrm{NO}_{3}\right)_{3} .9 \mathrm{H}_{2} \mathrm{O}\right)$ as starting materials. The purity of the constituent elements is $99.9 \%$ and is supplied by Merck, India. All the reagents used are of analytical grade 'AR' and are used without further purification. Metal salts are dissolved in $20 \mathrm{ml}$ of distilled water to form a clear solution and are overall assorted. The mixture is stirred with a magnetic stirrer until the reactants are completely dissolved. The citric acid $\mathrm{C}(\mathrm{OH})(\mathrm{COOH}) \quad\left(\mathrm{CH}_{2} \cdot \mathrm{COOH}\right)_{2} \cdot \mathrm{H}_{2} \mathrm{O} \quad(\mathrm{MW} 210.14)$ is utilized during this reaction. Citric acid possesses three carboxylic and one hydroxyl group for coordinating metal ions, thereby, aiding in the segregation of the solution from the homogenous mixture.

\section{Synthesis of Zinc Ferrite Nanoparticles}

A polycrystalline form of $\mathrm{ZnFe}_{2} \mathrm{O}_{4}$ has been prepared via citrate-nitrate precursor auto combustion technique by using the mixed metal nitrate salts to the citric acid solution in a molar ratio of $1: 1$. The $\mathrm{pH}$ value of the clear solution is highly acidic as it is one of the key factors in synthesizing nano-ferrites. Therefore, a required amount of ammonia solution is added to the above solution to maintain the $\mathrm{pH}$ of 7 . To increase the rate of reaction base catalysts are applied in the reaction. Dried gel is formed finally in the dehydration process. Further, the mixed solution is poured into a dish, heated and stirred to transform into an aerogel. Hence the gel formed is kept under dynamic vacuum oven at $100{ }^{\circ} \mathrm{C}$ for $26 \mathrm{~h}$ to remove the adsorbed water. During this process, the gel swells into a fluffy mass, which eventually breaks into brittle flakes. Finally, it is grounded to obtain a fine powder of zinc ferrite oxide prior to its usage in experiments [34, 35].

\section{Preparation of PVA Coated Magnetic Particles Modified Platinum Electrode}

Citrate-nitrate precursor prepared according to above method is pasted over the platinum electrode, dried for $30 \mathrm{~min}$ and then heated at $150{ }^{\circ} \mathrm{C}$ for $10 \mathrm{~min}$.
The above ferrite layer coated electrode is dipped in $0.3 \mathrm{wt} \%$ of PVA solution and kept for $6 \mathrm{~h}$ drying, before its usage in electrochemical studies.

\section{Preparation of Nutrient Media for Bacteria Culture}

Peptone $(2.5 \mathrm{~g})$ and beef extract $(1.5 \mathrm{~g})$ are dissolved in $500 \mathrm{ml}$ of distilled water in a conical flask and stirred continuously till both the component completely dissolves. The $\mathrm{pH}$ is adjusted to 7 by adding sodium hydroxide $(0.1 \mathrm{M})$ solution, and then the conical flask is sterilized using autoclave at $15 \mathrm{lbs}$ pressure for $25 \mathrm{~min}$. The strains are obtained from the lab stock, on the day before testing; organisms are sub-cultured in sterile selective broth media. After incubating culture for $18 \mathrm{~h}$, the suspension is used for the test. The subculture is prepared by dissolving $1 \mathrm{gm}$ of peptone and $10 \mathrm{~g}$ of mannitol in 1 liter of distilled water in the presence of $2 \mathrm{~g}$ of sodium chloride salt and stirred for $20 \mathrm{~min}$ to form a clear solution. The above solution is added to a mixture of $\mathrm{MgSO}_{4}(0.1 \mathrm{~g})$, $\mathrm{Na}_{2} \mathrm{HPO}_{4}(2.5 \mathrm{~g}), \mathrm{KH}_{2} \mathrm{PO}_{4}(0.2 \mathrm{~g})$, Bromothymol blue $(0.12 \mathrm{~g})$, sodium pyruvate $(10 \mathrm{~g})$ and agar $(15 \mathrm{~g})$ and stirred for $30 \mathrm{~min}$, subsequently autoclaving at $15 \mathrm{lbs}$ pressure for $25 \mathrm{~min}$. The prepared selective broth media is used for subculture test $[36,37]$.

\section{Characterization}

The sample is taken in the powder form for X-ray diffraction investigation using Rigaku $X$-ray diffractometer (Rigaku Miniflex II) with CuKa radiation (wavelength $\lambda=1.5406 \AA$ operated at $40 \mathrm{kV}$ and 35 $\mathrm{mA})$. The samples are rotated through an angle of 20 $70^{\circ}$ at a scanning speed of $2.9 \times 10^{-4} \mathrm{rad} / \mathrm{s}$. The SEM analysis is carried out after sputtering a thin conducting layer of gold using JEOL (JFC-1100E) ion sputtering device. Plate counting technique is used to count the number of $B$. Cereus bacterial cells present in per $\mathrm{ml}$ using Haemocytometer [38, 39].

The electrochemical studies are performed with a $\mathrm{CHI} 660$ D electrochemical workstation $(\mathrm{CH}$ Instruments, USA) attached with pico amp booster inside a Faraday cage. The electrochemical studies are carried out under three electrode system where, PVA coated magnetic nano-ferrite platinum plate is used as working electrodes, platinum wire is used as counter electrode and saturated calomel electrode (SCE) is used as reference electrode.

Tetrabutylammonium hexafluorophosphate $\left(\mathrm{TBAPF}_{6}\right)$, is obtained from Sigma Aldrich and is used 
without further purification as a supporting electrolyte. The buffer tablets of $\mathrm{pH} 4.0 \pm 0.05$ are obtained from Merck Chemicals and are used without further purification.

\section{RESULTS AND DISCUSSION}

\section{X-Ray Diffraction Spectroscopy}

Figure 1 shows the XRD patterns of $\mathrm{ZnFe}_{2} \mathrm{O}_{4}$ and PVA coated $\mathrm{ZnFe}_{2} \mathrm{O}_{4}$ prepared by citric auto combustion method analyzed by Rigaku X-ray diffractometer. The measurement is carried out from the range of $20^{\circ}$ to $80^{\circ}$ for both the samples. The characteristic peaks are observed at $10.48^{\circ}, 21.14^{\circ}$, $34.93^{\circ}, 55.78^{\circ}, 62.30^{\circ}$ and $72.71^{\circ}$ which correspond to the (220), (311), (400), (422), (511) and (440) planes respectively. It is observed that the intensity of the peaks decreases when coated with PVA, this reveals that the crystallinity has decreased.

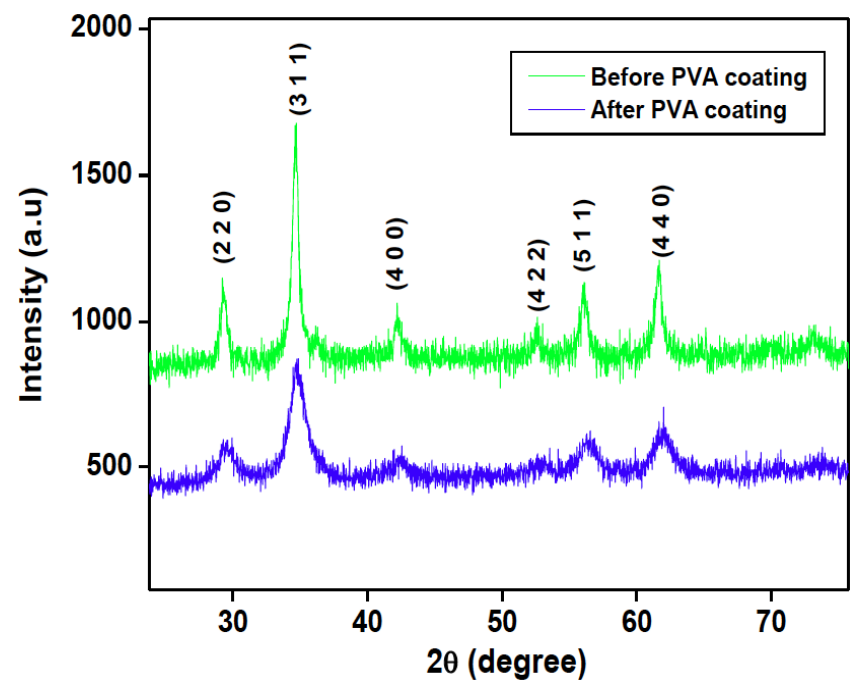

Figure 1: Shows the XRD spectra of samples; (before PVA coated) zinc ferrite treated for suspension of bacterial cells in the colloidal solution and (after PVA coated) PVA coated zinc ferrite prepared for electrochemical studies.

\section{Transmission Electron Microscopy}

The TEM image is employed to observe the shape and size of the nanocrystalline ferrites of $\mathrm{ZnFe}_{2} \mathrm{O}_{4}$ synthesized by citric auto combustion method. Figure 2a shows the TEM image of $\mathrm{ZnFe}_{2} \mathrm{O}_{4}$, which are $\sim 25$ $\mathrm{nm}$ to $50 \mathrm{~nm}$ in size. The image shows the dense assembly separated by definite grain boundaries. The particles size distribution is broader and therefore indicates that the ferrites nanoparticles are polycrystalline. The selected area electron diffraction (SAED) pattern is shown in Figure $\mathbf{2 b}$. It is observed that there is a formation of the concentric ring at the center accompanied by many circular bright spots indicating that the zinc ferrite is polycrystalline in nature. It is observed that crystalline plane observed from XRD matches well with the SAED pattern.
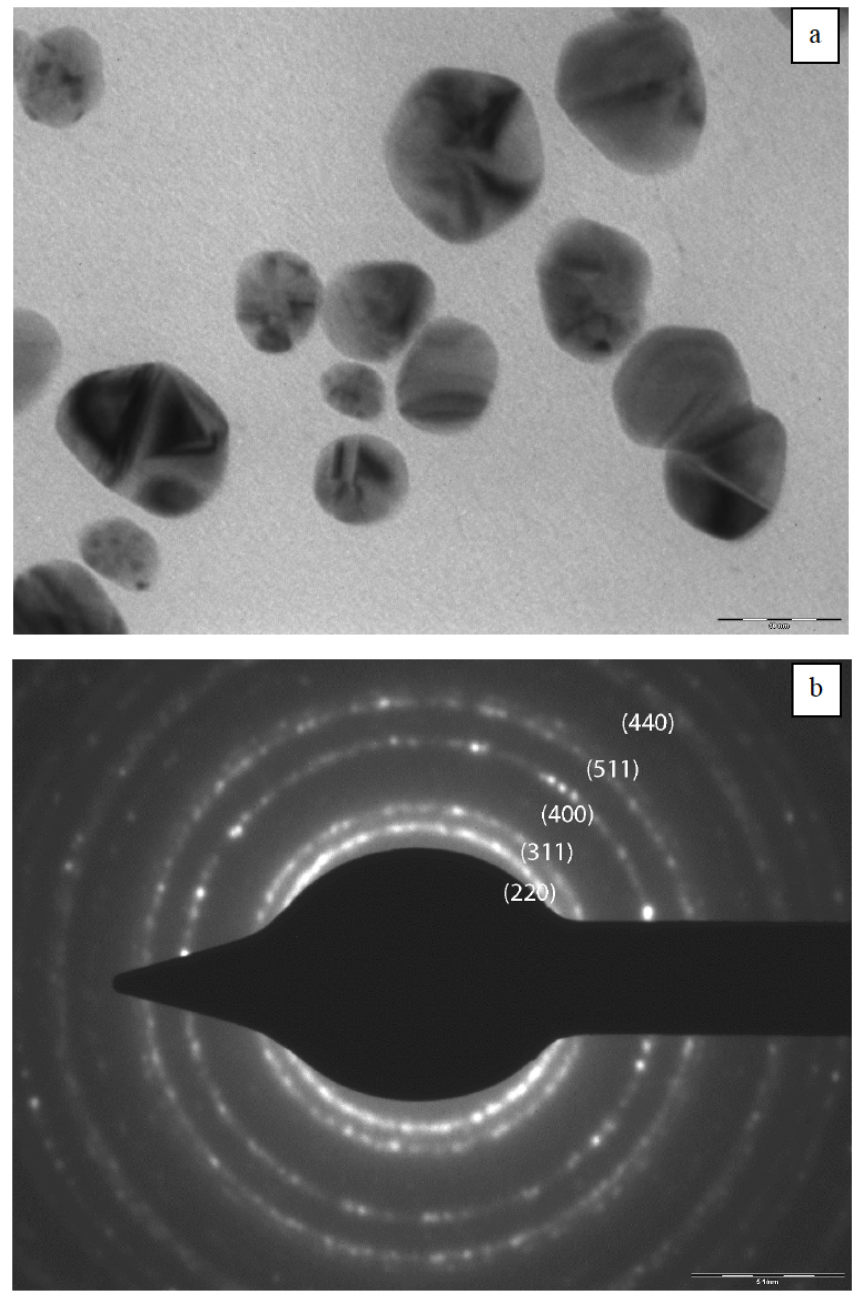

Figure 2: Shows the TEM images of (a) zinc ferrite treated for suspension of the bacterial cell in colloidal solution and (b) SAED image of zinc ferrite indicating the plane of nanoferrite.

\section{Treatment of B. Cereus with Magnetic Nanoparticles}

The $B$. Cereus bacterial subculture is harvested utilizing $0.3 \mathrm{~g}$ of mass taken in a single cell containing $20 \mathrm{ml}$ of distilled water which is stirred for $12 \mathrm{~h}$ as shown in Figure $\mathbf{3 a}$ and $\mathbf{3 g}$. When magnetic nanoparticles comes in proximity with $B$. Cereus, it is observed that as the period increases the bacteria coagulates with $\mathrm{ZnFe}_{2} \mathrm{O}_{4}$ nanoparticles (Figure $3 \mathbf{b}$ ). As a result the nanoparticles agglomerates with bacteria (Figure 3c) and starts to settle down (Figure $\mathbf{3 d}$ ). It is well known that zinc oxide particle shows good antibacterial response and the presence of $\mathrm{Fe}^{2+}$ ions which has more tendency towards the $\mathrm{OH}^{-}$ions helps 


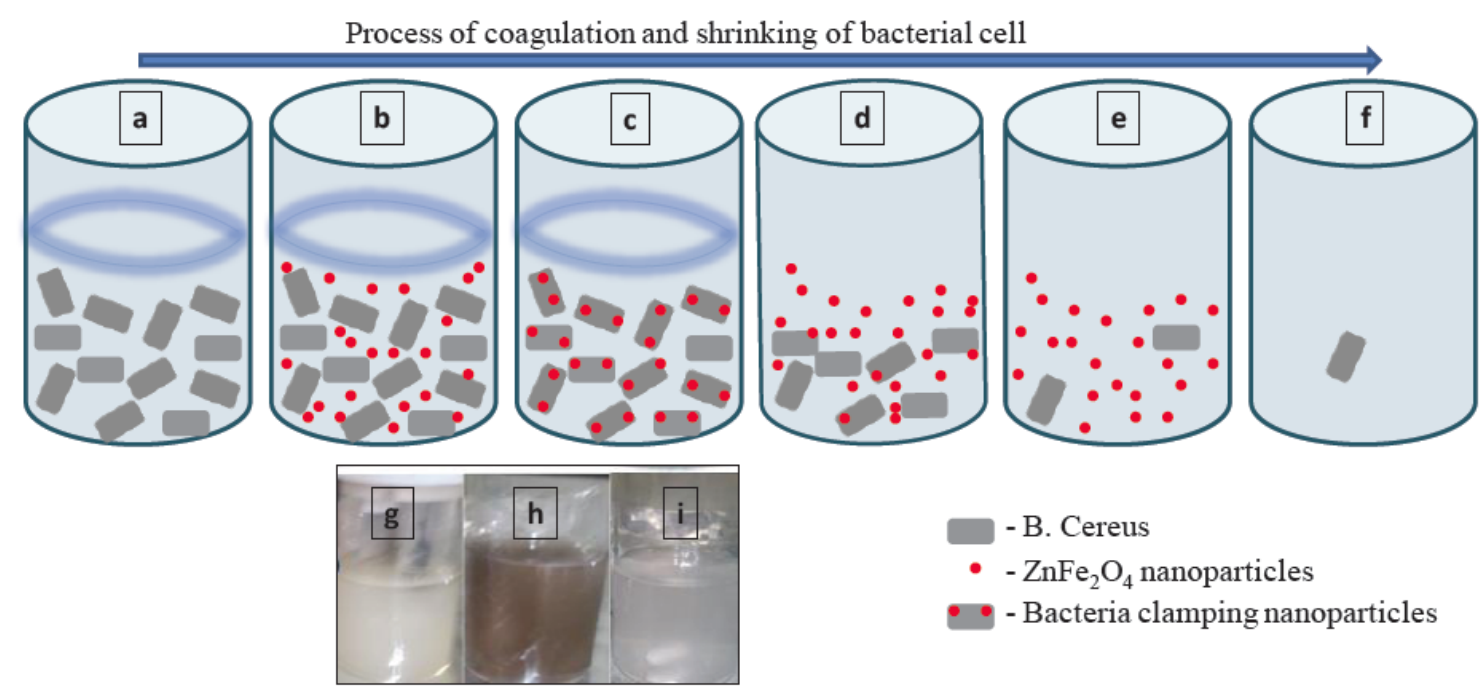

Figure 3: Shows the schematic diagram of treatment of nano-ferrites with colloidal bacterial cell in distilled water (a) $B$. Cereus (b) dispersion of $B$. Cereus and nanoferrites (c) clamping of $B$. Cereus and nanoferrites (d) Settling down of $B$. Cereus (e-f) Shrinking of bacterial cell with an inset of $(\mathbf{g})$ actual colloidal solution (h) when mixed with nano-ferrites and (i) filtered colourless aliquot.

in attachment over the cell wall of the bacteria. When the nanoparticles attaches to the bacteria wall, it destroys the cell wall due to the dehydrogenation of the tissue causing shrinking of the cell (Figure $3 e-f)$. The above solution is taken out at regular time intervals of $3 \mathrm{~h}, 6 \mathrm{~h}, 9 \mathrm{~h}$ and $12 \mathrm{~h}$ and cell counting is carried out by plate counting method. It is observed that as period increases, the shrinking also increases due to oxidation of cell tissues as shown in Table 1 . The colloidal magnetic nanoparticle based bacterial solution (Figure $\mathbf{3 h}$ ) is filtered separately till the aliquots become colorless (Figure $\mathbf{3 i}$ ) with different pore size filter paper (Whartman filter paper grade $0.1 \mu \mathrm{m}$ to $12 \mu \mathrm{m}$ ).

Further, $0.3 \mathrm{~g}$ of $B$. Cereus harvested mass is added in distilled water, and the amount of cell present in $1 \mathrm{ml}$ is calculated by plate counting method using Neubauer hemocytometer. It is observed that $1 \mathrm{ml}$ of colloidal solution contain 2,350,000 and its number can be reduced to less than one percentage using this technique. When treated once with the magnetic nanoparticles it is observed that from 2,050,000 per $\mathrm{ml}$ of bacterial cells, approximately $75 \%$ gets destroyed and shrunk when treated in the first cycle $(\sim 1,700,000$ per $\mathrm{ml}$ cells shrinks). Subsequent similar treatments result in less than $\sim 1 \%$ of the bacterial count.

Advantages of using magnetic zinc ferrite nanoparticles are easy to-synthesize, low cost [20] compatible with less expensive water soluble polymers and can be used for isolation of many other pathogenic bacteria [21-23].

\section{Cyclovoltammetry (CV) Measurements}

Figure 4 shows the results of cyclovoltammetry used to detect and isolate $B$. Cereus using PVA coated magnetic nano-ferrites modified platinum electrode from the sweeping voltage -3 to $3 \mathrm{~V}$ at the scan rate of $0.1 \mathrm{~s}$ in a single cell. It is observed that the oxidation peaks appeared between -0.2 to $-0.3 \mathrm{~V}$ and it is noted that after first segments of sweeping the $B$. Cereus

Table 1: Shows the Platelet Counting of $B$. Cereus after Regular Period Intervals

\begin{tabular}{|c|c|c|c|c|c|c|c|c|c|}
\hline \multirow[t]{2}{*}{ Trials } & \multirow[t]{2}{*}{ Oh } & \multicolumn{2}{|r|}{$3 h$} & \multicolumn{2}{|r|}{$6 h$} & \multicolumn{2}{|c|}{$9 h$} & \multicolumn{2}{|c|}{$12 \mathrm{~h}$} \\
\hline & & $\begin{array}{l}\text { Neat } \\
\text { (no of } \\
\text { units) }\end{array}$ & $\begin{array}{c}\text { Shrunk/ } \\
\text { ruptured } \\
\text { (no of units) }\end{array}$ & $\begin{array}{l}\text { Neat } \\
\text { (no of } \\
\text { units) }\end{array}$ & $\begin{array}{c}\text { Shrunk/ } \\
\text { ruptured } \\
\text { (no of units) }\end{array}$ & $\begin{array}{l}\text { Neat } \\
\text { (no of } \\
\text { units) }\end{array}$ & $\begin{array}{c}\text { Shrunk/ } \\
\text { ruptured } \\
\text { (no of units) }\end{array}$ & $\begin{array}{l}\text { Neat } \\
\text { (no of } \\
\text { units) }\end{array}$ & $\begin{array}{c}\text { Shrunk/ } \\
\text { ruptured } \\
\text { (no of units) }\end{array}$ \\
\hline 1 & 13 & 7 & 6 & 4 & 9 & 6 & 9 & 3 & 11 \\
\hline 2 & 11 & 5 & 6 & 6 & 7 & 5 & 7 & 6 & 10 \\
\hline 3 & 17 & 8 & 8 & 2 & 5 & 3 & 9 & 3 & 13 \\
\hline $\begin{array}{l}\text { Mean } \\
\text { count }\end{array}$ & 14 & 7 & 7 & 4 & 7 & 5 & 9 & 4 & 11 \\
\hline
\end{tabular}




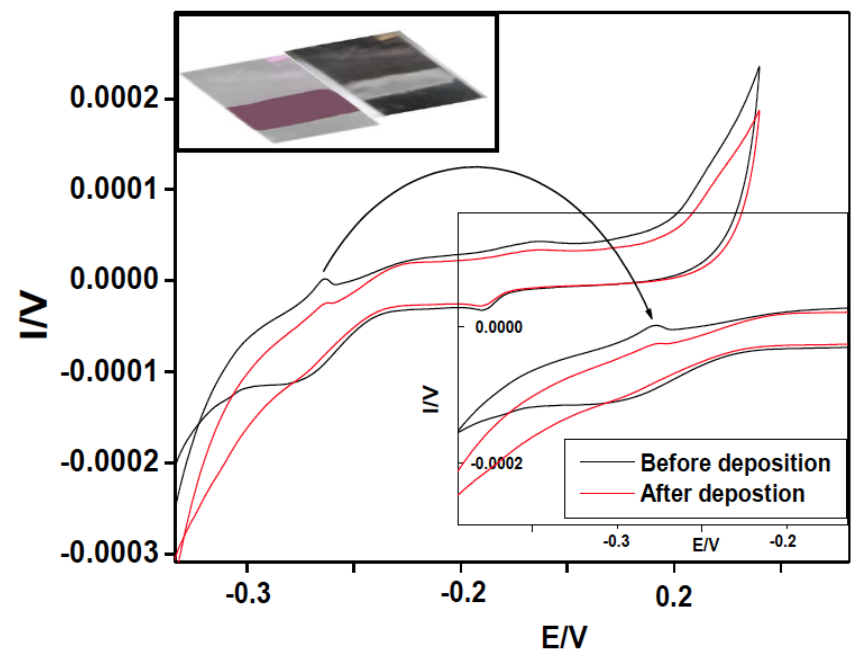

Figure 4: Shows the cyclovoltammetry graphs of colloidal $B$. Cereus; before and after deposition on nano-ferrites zone.

bacterial cells are attached to the PVA coated $\mathrm{ZnFe}_{2} \mathrm{O}_{4}$ modified platinum electrode as shown in inset figure. After first segments of running it is found that the internal curvature area decreases and this may be due to a lower concentration of bacterial cells in the electrolytic solution [40,41]. The peak is formed in between -0.2 to $0.3 \mathrm{~V}$ due to the oxidation of bacterial cell tissues, as a result, some cells are damaged. This possibly happens during oxidation of cell wall as it may have produced some toxins in the solution causing the change in the electrical resistance, therefore a peak is formed [42]. It is also interesting to note that the cells are aligned behind one another and move towards the working electrodes when the field is applied, Figure $\mathbf{5 b}$ as compared to SEM image of $B$. Cereus before applying the field Figure $\mathbf{5 a}$. In other words, there is contrasting difference between live cells as shown in
Figure $\mathbf{5 a}$ and flat collapsed cells as shown in Figure $5 b$.

\section{Sweep Step Function and Tafel Plot Analysis}

Sweep step function (SSF) graph shows the detection node of $B$. Cereus using modified platinum electrode with magnetic nano-ferrite. The graph is obtained by sweeping from -1 to $1 \mathrm{~V}$ at the constant bias voltage of $0.5 \mathrm{~V}$ at the scan rate of $0.1 \mathrm{~s}$ for $10 \mathrm{ml}$ of total volume of colloidal solution in a single cell as shown in Figure 6. It is observed that node is formed in between -0.2 to $-0.3 \mathrm{~V}$, may be because of the oxidation of the bacterial cell wall due to the presence of $\mathrm{Fe}^{+2}$ ions and $\mathrm{Zn}^{+2}$ which help dehydrolysis of bacterial cells resulting in a smaller generation of the current of $0.0027 \mu \mathrm{A}$. It also owes that when cell wall is ruptured various type of toxin released in the electrolytes may also be responsible for the change in electric resistance of the single cell circuit. The node is formed in SSF because there is a sudden change in the rate of flow of charge carriers in the electrochemical circuit [43]. The change in the electrical resistance in the single cell circuit can be predicted from Tafel plot. The Tafel plot for detection of $B$. Cereus using modified platinum electrode with applied voltage of -0.6 to $0.6 \mathrm{~V}$ at the scan rate of $0.1 \mathrm{~s}$ is as shown in Figure 7 . It is found that after running of first segments the potential drop from -0.17 to -0.25 indicates that there is an oxidation of bacterial cells and its oxidation rate decreases with increase in the number of cycles. This indicates that the potential drop is depended on the amount of $B$. Cereus deposited on the electrode and amount of bacterial cell shrink when the field is applied to the single electrochemical cell.
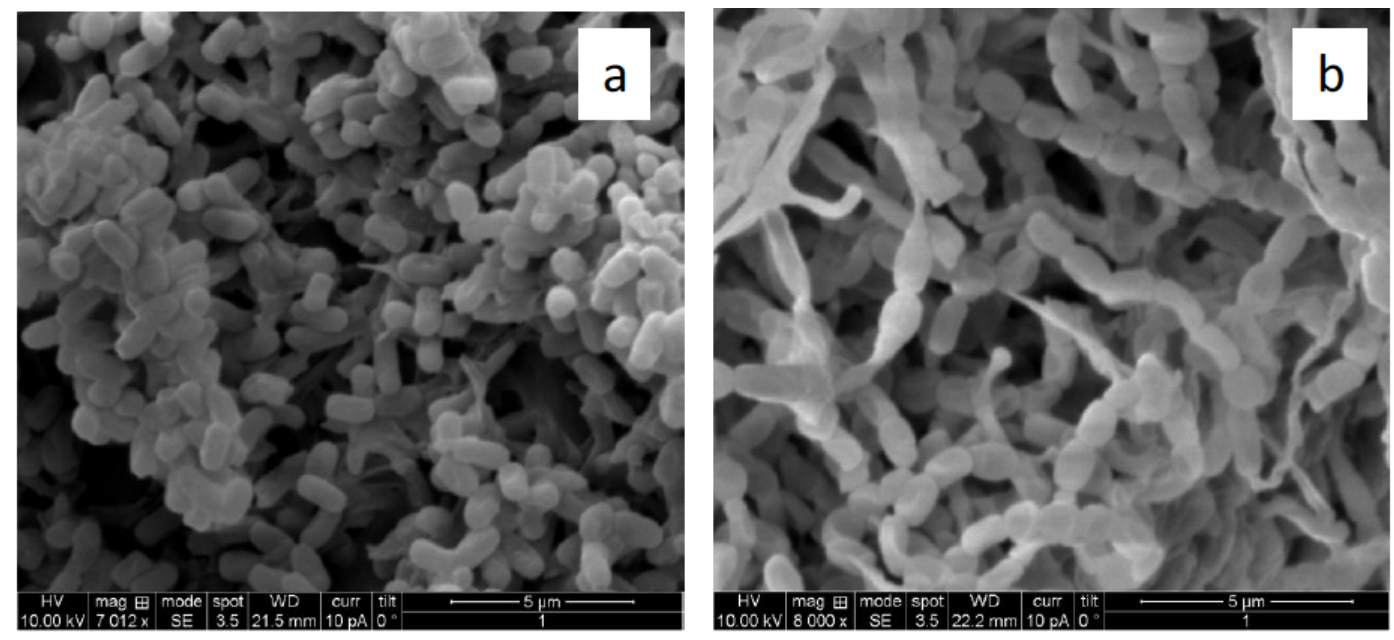

Figure 5: Shows the SEM image of (a) Bacillus cereus bacterial cell before depositing on modified platinum electrode and (b) Bacillus cereus bacterial cell after depositing on modified platinum electrode. 


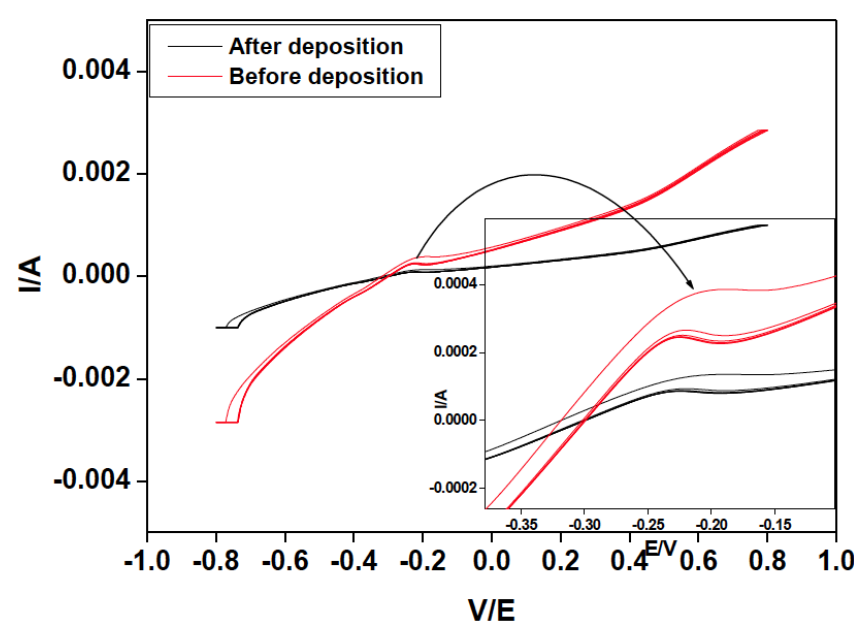

Figure 6: shows the swept step function (SSF) of the Bacillus cereus bacterial cell before and after depositing on modified platinum electrode at $0.5 \mathrm{~V}$.

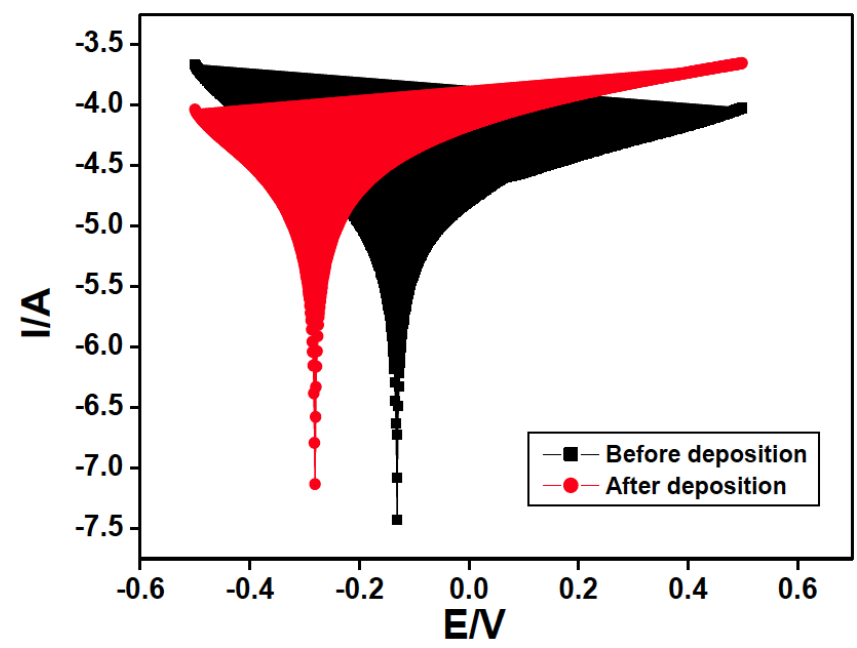

Figure 7: shows the Tafel plot of the Bacillus cereus bacterial cell before and after depositing on modified platinum electrode at constant applied voltage of $0.5 \mathrm{~V}$.

\section{AC Impedance Spectroscopy}

Figure 8 shows the Nyquist plot of $B$. Cereus isolated on PVA coated magnetic nano-ferrites modified platinum electrode from the applied frequency of $50 \mathrm{~Hz}$ to $1 \mathrm{kHz}$. In such a plot two distinct semicircle arcs are formed due to the electron transfer resistance ' $R_{\text {et }}$ ' and the internal resistance of the modified electrode. The decrease in the impedance reduces the area under the semicircle arc indicating the formation of series resistance to capacitance [44, 45], as a result, there is a decrease in the bulk resistance of the single cell circuit as shown in inset of Figure 8. First large semi arc formation is due to the resistance offered due to the oxidation of bacterial cell on the modified electrode and the second semi arc is offered due to the internal resistance because of the interface and grain boundaries of the magnetic nanoparticles $[46,47]$. The semicircle arc originated from two different points indicates that the relaxation times $(\tau)$ of the electron are different in every cycle of deposition. The relation time is calculated and is found to be $0.17 \mu$ s for the first arc formed at lower frequency and $0.14 \mu$ s for arc formed at higher frequency, before deposition of $B$. Cereus on the modified platinum electrode [48]. In the second segments, the relaxations are found to be $0.15 \mu \mathrm{s}$ and $0.12 \mu \mathrm{s}$. Hence, after the first cycle of deposition impedance value decreases with the decrease in the bacterial cell concentration in the electrochemical cell. This clearly indicates the $B$. Cereus is detected by using PVA coated magnetic nano-ferrites modified platinum electrode and can be isolated from the colloidal solution.

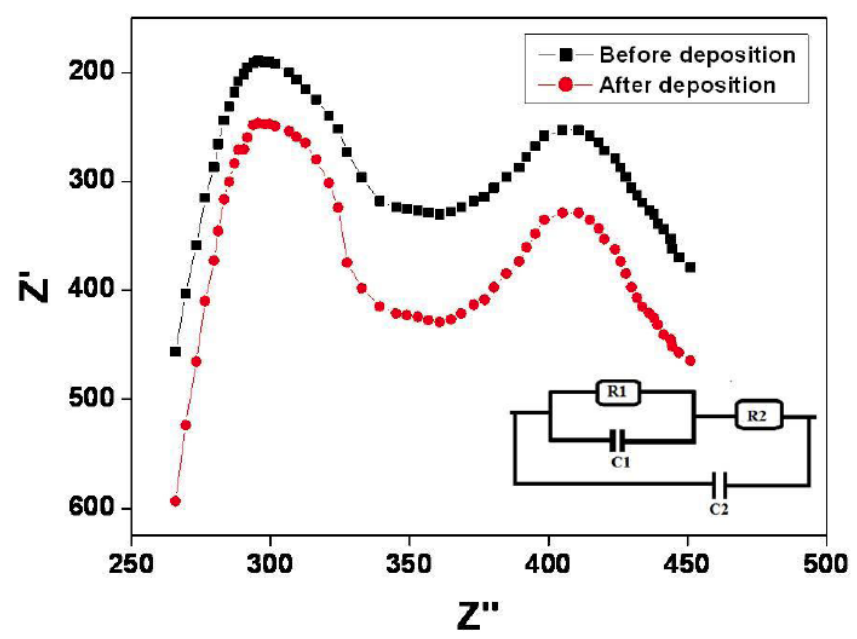

Figure 8: Shows the $\mathrm{AC}$ impedance spectra at $0.5 \mathrm{~V}$, and the inset shows the circuit design for the single electrochemical cell.

\section{CONCLUSION}

The magnetic zinc ferrite nanoparticles are prepared by using citric acid for isolation of bacterial cell from colloidal solution. The nanoferrites are treated with $0.3 \mathrm{gm}$ of the bacterial cell containing $20 \mathrm{ml}$ of distilled water and stirred for $12 \mathrm{~h}$. At regular time interval, the number of cells both shrink and unshrink are calculated employing plate counting method using haemocytometer. Nanoferrites are further characterized for structural and morphology analyses by XRD and TEM. From XRD spectra, it is found that the particles are spinal in structure and possess the average crystallite size of $7 \mathrm{~nm}$ which is in good agreement with TEM results. Various electrochemical parameters such as cyclovoltameter, sweep step function, Tafel plot, AC impedance are studied employing the modified platinum electrode. From CV 
graph, it is observed that the peaks are formed at -0.25 $\checkmark$ due to the oxidation of bacterial cell, which is further supported by sweep step function graph. After the first cycle of deposition, the electrode is analyzed through SEM to understand the arrangement of the bacterial cell over the zinc ferrite pattern. Hence, this is one of the low-cost, efficient technique to detect and isolate the Bacillus cereus from the colloidal solution.

\section{ACKNOWLEDGEMENT}

The financial support for this work is from DST/TM/WIT/2K15/228(G) and partially supported by the Ministry of Communication and Information Technology under a grant from the Centre of Excellence in Nanoelectronics, Phase II.

\section{REFERENCES}

[1] Fan $\mathrm{H}$, et al. A new electrochemical biosensor for DNA detection based on molecular recognition and lead sulfide nanoparticles. Anal Biochem 2011; 419(2): 168-172. https://doi.org/10.1016/j.ab.2011.08.005

[2] Lazcka O, Campo FJD, Muñoz FX. Pathogen detection: A perspective of traditional methods and biosensors. Biosens Bioelectron 2007; 22(7) 1205-1217.

https://doi.org/10.1016/j.bios.2006.06.036

[3] Shamansky LM, Davis CB, Stuart JK, Kuhr WG. Immobilization and detection of DNA on microfluidic chips. Talanta 2001; 55(5): 909-918. https://doi.org/10.1016/S0039-9140(01)00501-X

[4] Xu M, Wang R, Li Y. Rapid detection of Escherichia coli O157:H7 and Salmonella Typhimurium in foods using an electrochemical immunosensor based on screen-printed interdigitated microelectrode and immunomagnetic separation. Talanta 2016; 148: 200-208. https://doi.org/10.1016/j.talanta.2015.10.082

[5] Wang $Y, Y e ~ Z$, Ying $Y$. New Trends in Impedimetric Biosensors for the Detection of Foodborne Pathogenic Bacteria. Sensors 2012; 12(3): 3449-3471.

https://doi.org/10.3390/s120303449

[6] Lê HQA, Chebil S, Makrouf B, Sauriat-Dorizon H, Mandrand $B$, Korri-Youssoufi $H$. Effect of the size of electrode on electrochemical properties of ferrocene-functionalized polypyrrole towards DNA sensing. Talanta 2010; 81(4): 1250-1257.

https://doi.org/10.1016/j.talanta.2010.02.017

[7] Colquhoun KO, Timms S, Fricker CR. Detection of Escherichia coli in potable water using direct impedance technology. J Appl Bacteriol 1995; 79(6): 635-639. https://doi.org/10.1111/j.1365-2672.1995.tb00948.x

[8] Adányi N, Váradi M, Kim N, Szendrö I. Development of new immunosensors for determination of contaminants in food. Curr Appl Phys 2006; 6(2): 279-286.

https://doi.org/10.1016/j.cap.2005.07.057

[9] Varshney M, Li Y. Interdigitated array microelectrode based impedance biosensor coupled with magnetic nanoparticleantibody conjugates for detection of Escherichia coli O157:H7 in food samples. Biosens Bioelectron 2007; 22(11): 2408-2414.

https://doi.org/10.1016/j.bios.2006.08.030

[10] Varshney M, Li Y, Srinivasan B, Tung S. A label-free, microfluidics and interdigitated array microelectrode-based impedance biosensor in combination with nanoparticles immunoseparation for detection of Escherichia coli $\mathrm{O} 157: \mathrm{H} 7$ in food samples. Sens Actuators B Chem 2007; 128(1): 99107.

https://doi.org/10.1016/j.snb.2007.03.045

[11] Daniels JS, Pourmand N. Label-Free Impedance Biosensors: Opportunities and Challenges. Electroanalysis 2007; 19(12): 1239-1257.

https://doi.org/10.1002/elan.200603855

[12] Li D, et al. Label-free capacitive immunosensor based on quartz crystal Au electrode for rapid and sensitive detection of Escherichia coli O157:H7. Anal Chim Acta 2011; 687(1): 89-96. https://doi.org/10.1016/j.aca.2010.12.018

[13] Tlili C, Jaffrezic-Renault NJ, Martelet C, Korri-Youssoufi $\mathrm{H}$. Direct electrochemical probing of DNA hybridization on oligonucleotide-functionalized polypyrrole. Mater Sci Eng C 2008; 28(5): 848-854. https://doi.org/10.1016/j.msec.2007.10.061

[14] Barreiros dos Santos $M$, et al. Label-free ITO-based immunosensor for the detection of very low concentrations of pathogenic bacteria. Bioelectrochemistry 2015; 101: 146152.

https://doi.org/10.1016/j.bioelechem.2014.09.002

[15] Watts RJ, Wyeth MS, Finn DD, Teel AL. Optimization of $\mathrm{Ti} / \mathrm{SnO} 2-\mathrm{Sb} 2 \mathrm{O} 5$ anode preparation for electrochemical oxidation of organic contaminants in water and wastewater. $\mathrm{J}$ Appl Electrochem 2008; 38(1): 31-37. https://doi.org/10.1007/s10800-007-9391-4

[16] Zanin $\mathrm{H}$, et al. Diamond cylindrical anodes for electrochemical treatment of persistent compounds in aqueous solution. J Appl Electrochem 2013; 43(3): 323-330. https://doi.org/10.1007/s10800-012-0491-4

[17] Park M-K, Hirematha N, Weerakoon KA, Vaglenov KA, Barbaree JM, Chin BA. Effects of Surface Morphologies of Fresh Produce on the Performance of Phage-Based Magnetoelastic Biosensors. J Electrochem Soc 2013; 160(1): B6-B12.

https://doi.org/10.1149/2.059301jes

[18] Reiman RW, Atchley DH, Voorhees KJ. Indirect detection of Bacillus anthracis using real-time PCR to detect amplified gamma phage DNA. J Microbiol Methods 2007; 68(3): 651653.

https://doi.org/10.1016/j.mimet.2006.11.004

[19] Wang $M$, et al. Electrochemical detection of DNA immobilized on gold colloid particles modified self-assembled monolayer electrode with silver nanoparticle label. J Pharm Biomed Anal 2003; 3(5): 1117-1125. https://doi.org/10.1016/S0731-7085(03)00411-4

[20] Merkoçi A. Nanoparticles-based strategies for DNA, protein and cell sensors. Biosens Bioelectron 2010; 26(4): 11641177.

https://doi.org/10.1016/j.bios.2010.07.028

[21] Torres-Chavolla E, Alocilja EC. Nanoparticle based DNA biosensor for tuberculosis detection using thermophilic helicase-dependent isothermal amplification. Biosens Bioelectron 2011; 26(11): 4614-4618.

https://doi.org/10.1016/j.bios.2011.04.055

[22] Yang $H$, Zhou H, Hao H, Gong Q, Nie K. Detection of Escherichia coli with a label-free impedimetric biosensor based on lectin functionalized mixed self-assembled monolayer. Sens Actuators B Chem 2016; 229: 297-304. https://doi.org/10.1016/j.snb.2015.08.034

[23] Geng $P$, et al. Self-assembled monolayers-based immunosensor for detection of Escherichia coli using electrochemical impedance spectroscopy. Electrochimica Acta 2008; 53(14): 4663-4668. https://doi.org/10.1016/j.electacta.2008.01.037

[24] Izadi Z, Sheikh-Zeinoddin M, Ensafi AA, Soleimanian-Zad S. Fabrication of an electrochemical DNA-based biosensor for 
Bacillus cereus detection in milk and infant formula. Biosens Bioelectron 2016; 80: 582-589.

https://doi.org/10.1016/j.bios.2016.02.032

[25] Kang X, Pang G, Chen Q, Liang X. Fabrication of Bacillus cereus electrochemical immunosensor based on doublelayer gold nanoparticles and chitosan. Sens Actuators B Chem 2013; 177: 1010-1016.

https://doi.org/10.1016/j.snb.2012.12.018

[26] Porcellato D, Narvhus J, Skeie SB. Detection and quantification of Bacillus cereus group in milk by droplet digital PCR. J Microbiol Methods 2016; 127: 1-6. https://doi: 10.1016/j.mimet.2016.05.012

[27] Maalouf R, Hassen WM, Fournier-Wirth C, Coste J, JaffrezicRenault N. Comparison of two innovatives approaches for bacterial detection: paramagnetic nanoparticles and selfassembled multilayer processes. Microchim Acta 2008; 163(3-4): 157-161. https://doi.org/10.1007/s00604-008-0008-3

[28] Sohni Y, Kanjilal S, Kapur V. Cloning and development of synthetic internal amplification control for Bacillus anthracis real-time polymerase chain reaction assays. Diagn Microbiol Infect Dis 2008; 61(4): 471-475.

https://doi.org/10.1016/j.diagmicrobio.2008.04.005

[29] Graham DL, Ferreira HA, Feliciano N, Freitas PP, Clarke LA, Amaral MD. Magnetic field-assisted DNA hybridisation and simultaneous detection using micron-sized spin-valve sensors and magnetic nanoparticles. Sens Actuators B Chem 2005; 107(2): 936-944.

https://doi.org/10.1016/j.snb.2004.12.071

[30] Martin E, Savadogo O, Guiot SR, Tartakovsky B. Electrochemical characterization of anodic biofilm development in a microbial fuel cell. J Appl Electrochem 2013; 43(5): 533-540. https://doi.org/10.1007/s10800-013-0537-2

[31] Wilkins JR. Use of platinum electrodes for the electrochemical detection of bacteria. Appl Environ Microbiol 1978.

[32] Zhang D, Chen S, Qin L, Li R, Wang P, Li Y. The novel immunobiosensors for detection of Escherichia coli O157:H7 using electrochemical impedance spectroscopy. presented at the Annual International Conference of the IEEE Engineering in Medicine and Biology - Proceedings 2005; vol. 7 pp. 71117113.

[33] Ding $\mathrm{C}$, Zhong $\mathrm{H}$, Zhang $\mathrm{S}$. Ultrasensitive flow injection chemiluminescence detection of DNA hybridization using nanoCuS tags. Biosens Bioelectron 2008; 23(8): 1314-1318. https://doi.org/10.1016/j.bios.2007.12.005

[34] Hashim $M$, et al. Preparation and characterization chemistry of nano-crystalline Ni-Cu-Zn ferrite. J Alloys Compd 2013; 549: 348-357.

https://doi.org/10.1016/j.jallcom.2012.08.039

[35] Ch and Ladole R.A. Preparation and Characterization of Spinel Zinc Ferrite ZnFe2O4. Int J Chem Sci 2012; 10(3): 1230-1234.

[36] Jiang $\mathrm{X}$, Chen $\mathrm{K}$, Han $\mathrm{H}$, Ultrasensitive electrochemical detection of Bacillus thuringiensis transgenic sequence based on in situ $\mathrm{Ag}$ nanoparticles aggregates induced by biotin-streptavidin system. Biosens Bioelectron 2011; 28(1): 464-468.

https://doi.org/10.1016/j.bios.2011.07.042
[37] Kerman K, Matsubara Y, Morita Y, Takamura Y, Tamiya E. Peptide nucleic acid modified magnetic beads for intercalator based electrochemical detection of DNA hybridization. Sci Technol Adv Mater 2004; 5(3): 351-357. https://doi.org/10.1016/j.stam.2004.01.009

[38] Setterington EB, Alocilja EC. Electrochemical Biosensor for Rapid and Sensitive Detection of Magnetically Extracted Bacterial Pathogens. Biosensors 2012; 2(1): 15-31. https://doi.org/10.3390/bios2010015

[39] Shabani A, Marquette CA, Mandeville R, Lawrence MF. Carbon microarrays for the direct impedimetric detection of Bacillus anthracis using Gamma phages as probes. Analyst 2013; 138(5): 1434-1440. https://doi.org/10.1039/c3an36830k

[40] Xu M, Wang R, Li Y. Electrochemical biosensors for rapid detection of Escherichia coli O157:H7. Talanta 2017; 162: 511-522. https://doi.org/10.1016/j.talanta.2016.10.050

[41] Yang L, Bashir R. Electrical/electrochemical impedance for rapid detection of foodborne pathogenic bacteria. Biotechnol Adv 2008; 26(2): 135-150.

https://doi.org/10.1016/j.biotechadv.2007.10.003

[42] Mannoor MS, Zhang S, Link AJ, McAlpine MC. Electrical detection of pathogenic bacteria via immobilized antimicrobial peptides. Proc Natl Acad Sci 2010; 107(45): 19207-19212. https://doi.org/10.1073/pnas.1008768107

[43] Liao LB, Xiao XM. Electronic detection of DNA utilizing ferrocenyl peptide conjugates probe. Sens Actuators B Chem 2006; 115(1): 465-472. https://doi.org/10.1016/j.snb.2005.10.010

[44] Maalouf $\mathrm{R}$, et al. Label-Free Detection of Bacteria by Electrochemical Impedance Spectroscopy: Comparison to Surface Plasmon Resonance. Anal Chem 2007; 79(13): 4879-4886.

https://doi.org/10.1021/ac070085n

[45] Li Y, et al. Impedance based detection of pathogenic E. coli O157:H7 using a ferrocene-antimicrobial peptide modified biosensor. Biosens Bioelectron 2014; 58: 193-199. https://doi.org/10.1016/j.bios.2014.02.045

[46] Barreiros dos Santos M, Agusil JP, Prieto-Simón B, Sporer C, Teixeira V, Samitier J. Highly sensitive detection of pathogen Escherichia coli $\mathrm{O} 157: \mathrm{H} 7$ by electrochemical impedance spectroscopy. Biosens Bioelectron 2013; 45: 174-180. https://doi.org/10.1016/j.bios.2013.01.009

[47] Güner A, Çevik E, Şenel M, Alpsoy L. An electrochemica immunosensor for sensitive detection of Escherichia coli O157:H7 by using chitosan, MWCNT, polypyrrole with gold nanoparticles hybrid sensing platform. Food Chem 2017; 229: 358-365.

https://doi.org/10.1016/j.foodchem.2017.02.083

[48] Escamilla-Gómez V, Campuzano S, Pedrero M, Pingarrón JM. Gold screen-printed-based impedimetric immunobiosensors for direct and sensitive Escherichia coli quantisation. Biosens Bioelectron 2009; 24(11): 3365-3371. https://doi.org/10.1016/j.bios.2009.04.047 